\title{
Article/Artigo
}

\section{Epidemiological aspects of dengue in Aracaju, State of Sergipe, Brazil}

\author{
Aspectos epidemiológicos da dengue em Aracaju, Estado de Sergipe, Brasil
}

\author{
José Antonio Barreto Alves ${ }^{1,2}$, Jokasta Rodrigues Santos ${ }^{3}$, Emanuelle Nabuco de Mendonça ${ }^{3}$, Ana Cristina Freire Abud ${ }^{3,4}$, \\ Mariangela da Silva Nunes ${ }^{2,3}$, Ricardo Fakhouri ${ }^{5}$, Ana Dorcas de Melo Inagaki ${ }^{3,4}$, Murilo Marchioro ${ }^{2}$ \\ and Angelo Roberto Antoniolli ${ }^{2}$
}

\begin{abstract}
Introduction: The dengue fever remains to be a disease of serious public health concern, and its incidence has increased in the past decades. This study aimed to characterize the epidemiological incidence of dengue in the period 2001-2010. Methods: This is an epidemiological study of dengue in the municipality of Aracaju, state of Sergipe, in the period between 2001 and 2010, whose data were obtained from the Information System of Diseases Notifications. A descriptive analysis of the number of confirmed cases of dengue, according to year, semester, sanitary district, age, and sex, was performed. Results: There were 16,462 confirmed cases, especially in 2008, which obtained the highest incidence of the disease, with 10,485 confirmed cases. The first semester obtained the highest registration of cases during the years of research; this was predominated by females between 15 and 49 years old. With regard to the territorial distribution, the second district of the municipality obtained the highest number of cases. Conclusions: In 2008, in the City of Aracaju, SE, a significant increase in the proportion of dengue cases compared with other years was verified. However, a fast decline in the other years was observed, possibly because of the intensification of preventive actions to combat the mosquito that transmits the dengue virus.
\end{abstract}

Keywords: Dengue. Epidemiology. Disease notification. Infectious diseases.

\section{RESUMO}

Introdução: A dengue permanece como uma doença de elevada significância para a saúde pública e sua incidência tem aumentado nas últimas décadas. Este estudo objetivou caracterizar a incidência epidemiológica da dengue no período de 2001-2010. Métodos: Trata-se de um estudo epidemiológico da dengue no município de Aracaju, Sergipe, no período de 2001 a 2010, cujos dados foram obtidos do Sistema de Informação de Agravos de Notificações. Foi realizada a análise descritiva do número de casos confirmados de dengue segundo ano, semestre, distrito sanitário, faixa etária e sexo. Resultados: Foram confirmados 16.462 casos, com destaque para o ano de 2008, o qual obteve maior incidência da doença, com 10.485 casos confirmados. O primeiro semestre obteve maior registro dos casos em todos os anos da pesquisa, com predomínio do sexo feminino e da faixa etária de 15-49 anos. Com relação à distribuição territorial, destaque para o segundo distrito do município que apresentou maior número de casos. Conclusões: Verificou-se que no ano de 2008, na Cidade de Aracaju, SE, houve aumento significativo da proporção de casos de dengue em relação aos demais anos. No entanto, nota-se um declínio vertiginoso nos anos posteriores, possivelmente devido à intensificação de ações de prevenção e combate ao mosquito transmissor do vírus da dengue. Palavras-chaves: Dengue. Epidemiologia. Notificação de doenças. Doenças infecciosas.

1. Faculdade de Enfermagem, Universidade Federal de Sergipe, Lagarto, SE. 2. Programa de Pós-Graduação em Ciências da Saúde, Universidade Federal de Sergipe, Aracaju, SE. 3. Departamento de Enfermagem, Universidade Federal de Sergipe, Aracaju, SE. 4. Programa de Pós-Graduação em Ciências Médicas, Universidade de São Paulo, Ribeirão Preto, SP. 5. Departamento de Medicina, Universidade Federal de Sergipe, Aracaju, SE.

Address to: Dr. José Antonio Barreto Alves. Av. Beira Mar 280/1202, Edifício Lauro Porto, Bairro 13 de Julho, 49020-010 Aracaju, SE, Brasil.

Phone: 5579 8102-7030; 79 3105-6550

e-mail: antoniobalves@gmail.com

Received in 20/03/2011

Accepted in 28/04/2011

\section{INTRODUCTION}

The gravity of infections caused by the dengue virus, as well as the strength of its reemergence in several continents, represented by the increase of its incidence in the last decades has placed this disease as a priority in the agenda of national and international institutions responsible for health protection of the population, representing a challenge for public health ${ }^{1}$.

Approximately 2.5 billion people, in more than 100 countries, are exposed to the risk of its contraction in urban, peri-urban, and rural areas in the tropics and subtropics ${ }^{2-3}$. Dengue is an acute infectious disease, whose etiological agent belongs to the Flaviridae family, which has four known serotypes (DEN-1, DEN-2, DEN-3, and DEN-4) and could be transmitted by insect bites with urban habits; its principal vector is the Aedes aegypti ${ }^{4}$. Other factors, such as temperature and rainfall, could affect its survival, the vector reproduction, and the changes in its distribution and density ${ }^{5}$.

It appears as a febrile acute illness and presents an ample clinical spectrum, from oligosymptomatic forms to several clinical cases with bleeding and shock, which can evolve to death ${ }^{4}$.

The individuals of both sexes are affected, yet there are studies that show a higher incidence in women than in men. People of all ages are susceptible to acquire this infection; however, the highest incidence of cases in older age groups is a pattern observed in undamaged areas ${ }^{6}$.

The open spaces in the scientific knowledge regarding various aspects of this viral infection, especially referring to its epidemiological patterns, indicate a necessity of conducting investigations that describe the epidemiological profile and, therefore, contribute to the improvement of preventive actions ${ }^{7}$. This study intends to describe the epidemiological profile of dengue in the municipality of Aracaju, in the period between 2001 and 2010 . 


\section{METHODS}

This is an epidemiological study of descriptive and retrospective type, performed in the city of Aracaju, state of Sergipe, Brazil, which is divided in four sanitary districts. The data were obtained from the Information System of Diseases Notifications, whose intent is to register data generated routinely from the System of Epidemiological Vigilance/Ministry of Health by means of reporting files of compulsory diseases. This study was composed of all confirmed cases of dengue registered between January 2001 and July 2010.

The data analysis was executed by means of descriptive statistics, whose data were filed in a computerized database using the software program SPSS (Statistical Package for the Social Sciences) 16.0 version and presented as a chart. Some statistic measures, such as minimum, maximum, average, and median, were calculated. To determine the significance of dengue cases between two groups, the Mann-Whitney U test was utilized, and for more than two groups, the Kruskal Wallis test was applied. For the whole study, we considered the significance level of $5 \%(\mathrm{p}<0.05)$.

\section{Ethical considerations}

For the realization of this study, an authorization of the Epidemiological Vigilance Coordination was previously solicited. Due to the utilization of secondary data from the Information System of Diseases Notifications, the approval of the Ethics Committee was substituted for the terms of data use signed by the Health Secretary.

\section{RESULTS}

The descriptive analysis of the number of dengue cases in the municipality of Aracaju from January 2001 to July 2010 is presented in Table 1, which shows that the year 2008 had the highest number of dengue cases with a maximum 4,494 and a minimum of six. The lowest number of cases occurred in 2009, with a minimum of zero and a maximum of 76 . This difference was statistically significant $(\mathrm{p}<0.001)$.

With regard to the semester with the highest incidence of dengue in all these years, there was predominance on the first (January-June), with a minimum of 55, a maximum of 10,322, and an average of 1,465 cases. Note that the data for 2010 are partials, from January to July, as shown in Table 2.

The spatial distribution of confirmed cases by districts of the municipality of Aracaju shows that the second district presented, in absolute number, the highest number of cases, and the fourth district had the lowest. However, there was no statistical significance. For the analysis of the association between the number of dengue cases and the district of occurrence, 222 cases were excluded because of the inexistence of address or mismatched address according to the cartographic base.

With regard to sex, there was a predominance of females with 9,731 cases, having a maximum of 6,074 , a minimum of 36 , and an average of 973 . It was verified that regarding the age group, there was a higher number of confirmed cases between 15 and 19 years old, with a total of 10,252, a maximum of 5,906, a minimum of 36 , and an average of 1,025 . A statistical significance $(\mathrm{p}=0.051)$ was not observed; however, from the data obtained, a higher incidence of confirmed cases could be inferred for this age group.
Regarding the incidence of dengue, the period with higher incidence was April 2008, with 837 cases per 100,000 inhabitants. In December 2009, any notification was not verified as observed in Table 3. The incidence was calculated only from 2001 to 2009 because the population estimates for 2010 was still in the collection process by the Instituto Brasileiro de Geografia e Estatística (IBGE) census.

TABLE 1 - Distribution of confirmed dengue cases according to year in Aracaju, Sergipe, 2001-2010.

\begin{tabular}{lrrrrrr}
\hline Year & Total & Minimum & Maximum & Average & Median & $\mathbf{p}$ \\
\hline 2001 & 1,479 & 4 & 444 & 123 & 97 & $<0.001^{*}$ \\
\hline 2002 & 1,879 & 16 & 325 & 157 & 152 & \\
\hline 2003 & 1,235 & 26 & 286 & 103 & 103 & \\
\hline 2004 & 159 & 1 & 21 & 13 & 17 & \\
\hline 2005 & 255 & 2 & 71 & 23 & 12 & \\
\hline 2006 & 341 & 2 & 105 & 28 & 18 & \\
\hline 2007 & 252 & 9 & 49 & 21 & 17 & \\
\hline 2008 & 10,485 & 6 & 4,494 & 874 & 119 & \\
\hline 2009 & 318 & 0 & 76 & 26 & 16 & \\
\hline 2010 & 59 & 2 & 19 & 8 & 6 & \\
\hline
\end{tabular}

*p value of the Kruskal Wallis test.

TABLE 2 - Distribution of the number of confirmed dengue cases according to semester, sanitary district, sex, and age group in Aracaju, Sergipe, 2001-2010.

\begin{tabular}{lrrrrrc}
\hline Variables & Total & Minimum & Maximum & Average & Median & $\mathbf{p}$ \\
\hline $\begin{array}{l}\text { Semester } \\
\text { first }\end{array}$ & 14,652 & 55 & 10,322 & 1,465 & 257 & $0.218^{\mathrm{a}}$ \\
second & 1,810 & 4 & 517 & 181 & 148 & \\
\hline District* & & & & & & \\
$1^{\text {st }}$ & 4,020 & 19 & 2,377 & 402 & 119 & $0.563^{\mathrm{a}}$ \\
$2^{\text {nd }}$ & 4,902 & 21 & 2,774 & 490 & 102 & \\
$3^{\text {rd }}$ & 3,889 & 11 & 2,710 & 389 & 58 & \\
$4^{\text {th }}$ & 3,429 & 8 & 2,443 & 343 & 86 & \\
\hline
\end{tabular}

\begin{tabular}{|c|c|c|c|c|c|c|}
\hline \multicolumn{7}{|l|}{ Gender } \\
\hline male & 6,731 & 23 & 4,411 & 673 & 138 & $0.280^{\mathrm{b}}$ \\
\hline female & 9,731 & 36 & 6,074 & 973 & 191 & \\
\hline \multicolumn{7}{|c|}{ Age group (years) } \\
\hline$\leq 14$ & 4,358 & 12 & 3,598 & 436 & 61 & $0.051^{\mathrm{a}}$ \\
\hline 15 to 49 & 10,252 & 36 & 5,906 & 1,025 & 231 & \\
\hline$\geq 50$ & 1,852 & 11 & 981 & 185 & 45 & \\
\hline
\end{tabular}

${ }^{\mathrm{a}} \mathrm{p}$ value of the Kruskal Wallis test, ${ }^{\mathbf{b}} \mathrm{p}$ value of the Mann-Whitney U test, ${ }^{*} 222$ case were excluded.

TABLE 3 - Incidence of confirmed dengue cases per 100,000 inhabitants by month and year in Aracaju, Sergipe, 2001-2009.

\begin{tabular}{lrrrrrrrrr}
\hline Month & $\mathbf{2 0 0 1}$ & $\mathbf{2 0 0 2}$ & $\mathbf{2 0 0 3}$ & $\mathbf{2 0 0 4}$ & $\mathbf{2 0 0 5}$ & $\mathbf{2 0 0 6}$ & $\mathbf{2 0 0 7}$ & $\mathbf{2 0 0 8}$ & $\mathbf{2 0 0 9}$ \\
\hline January & 17 & 22 & 10 & 4 & 0,4 & 3 & 2 & 26 & 5 \\
\hline February & 22 & 36 & 10 & 3 & 0 & 2 & 2 & 29 & 3 \\
\hline March & 35 & 61 & 19 & 4 & 2 & 3 & 2 & 178 & 14 \\
\hline April & 38 & 69 & 36 & 1 & 4 & 7 & 3 & 837 & 14 \\
\hline May & 95 & 57 & 60 & 3 & 4 & 21 & 2 & 686 & 11 \\
\hline June & 55 & 44 & 49 & 4 & 13 & 11 & 3 & 167 & 5 \\
\hline July & 27 & 42 & 27 & 3 & 14 & 7 & 4 & 19 & 2 \\
\hline August & 20 & 28 & 18 & 3 & 6 & 5 & 9 & 4 & 3 \\
\hline September & 3 & 11 & 11 & 3 & 2 & 4 & 6 & 2 & 1 \\
\hline October & 8 & 13 & 7 & 0.4 & 2 & 2 & 3 & 1 & 1 \\
\hline November & 2 & 11 & 6 & 0.2 & 1 & 2 & 4 & 3 & 1 \\
\hline December & 1 & 3 & 5 & 1 & 2 & 0.4 & 7 & 2 & 0 \\
\hline Total & $\mathbf{3 2 3}$ & $\mathbf{3 9 7}$ & $\mathbf{2 5 8}$ & $\mathbf{2 9 . 6}$ & $\mathbf{5 0 . 4}$ & $\mathbf{6 7 . 4}$ & $\mathbf{4 7}$ & $\mathbf{1 , 9 5 4}$ & $\mathbf{6 0}$ \\
\hline
\end{tabular}




\section{DISCUSSION}

The data obtained in this study show that there was a higher occurrence of dengue cases in the years 2002 and 2008, with incidence coefficients of 397 and 1,954 per 100,000 inhabitants, respectively. In January 2001, an introduction of the serotype DENV-3 was confirmed in Brazil; this was isolated from an individual resident in Rio de Janeiro who had been sick in December 2000. This serotype was responsible for the 2002 epidemic in the country, when approximately 800,000 cases were notified, which represented approximately $80 \%$ of the occurrences in the American continent ${ }^{8}$.

In Aracaju, in the same year, 1,879 cases were notified. After the year 2002, there was a progressive fall of confirmed cases, with a new incidence increase from 2005, culminating in 2008, with more than 700,000 cases that resulted in approximately 45,000 hospitalizations for dengue all over the country, as registered by the Ministry of Health'.

During the dengue epidemic of 2008, the Epidemiological Vigilance Administration of the Municipal Office of Health in Aracaju had as notification sources the dial health (telephonic central that served as a notification source for a posterior epidemiological investigation of the cases), the basic health units, the public and private hospitals (through the Control Commission of Hospital Infection), the laboratory of clinical analysis (by means of automatic sending of the positive exams results to the Municipal Office of Health), and the private clinics, wherein the doctors made notifications of suspicious cases.

In 2009, the Municipal Office of Health of Aracaju executed weekly activities with a task force composed of agents of epidemic. Moreover, there was a training of the professionals and an incessant awareness work with the population in 2009. The hypothesis that these actions helped on the reduction of $97 \%$ of dengue cases in Aracaju, when compared with the previous year, must be considered in the data analysis, as shown in Table $\mathbf{1 .}$

Another factor to be considered is the population immunity, as the susceptive addiction by birth, migration, or immunity loss may not have been sufficient to keep the pathogen circulating endemically, as cited by Câmara and Santos ${ }^{10}$.

In this study, the most number of notification cases confirmed was concentrated in the first semester for all the researched years, coinciding with the months that have a hotter weather and summer rains. A similar observation was seen in a study ${ }^{11}$ in which the highest concentration of notifications also occurred in the first semester of the year, especially in April, May, and June. According to the study ${ }^{12}$, this significant seasonal incidence of dengue in hot months is associated with the known sensibility of the Aedes aegypti's reproductive cycle and the temperature variations. In months in which there is a reduction in temperature, that is, in the second half of the year, the cases of dengue are reduced significantly.

Nevertheless, the study ${ }^{13}$ emphasizes that, even with incidence values much lower than the ones from January to May, the months between September and December should also be included for cases notification to identify the highest number of sectors with transmission, prioritizing and anticipating the vector combat. The execution of examinations of febrile cases, independent of dengue suspicion, or even the execution of serological investigations is an important arrangement to identify the silent transmission.
The function of the housing conditions and income as intensity determinants of disease transmission presents prominence in the study ${ }^{14}$ in the municipality of Rio de Janeiro, which demonstrated that there exists a relation between the precariousness of basic sanitation services and the emergence of dengue epidemics. However, a study ${ }^{13}$ performed in Salvador (Bahia) demonstrated that even areas with more favorable socioeconomic conditions can present high risks of transmission. This is probably caused by observed habits such as water plant cultivation, a higher consumption of disposables, as well as the availability of pools, usually without treatment, constituting important vector breeding areas.

In the present study, the areas with the highest number of confirmed cases were the second and first districts, with 4,902 and 4,020 cases, respectively. In these districts, there is a prominence of neighborhoods that have precarious environmental sanitation conditions, deficit in the continuous water supply, inappropriate collection and disposal of solid wastes, and lack of clean water storage in residence, thus encouraging mosquito breeding that corroborates with study ${ }^{14}$ findings.

With regard to sex, the highest occurrence of confirmed cases of dengue in women is a pattern already reported by studies that affirm that this group is more affected, owing to the vector's residential characteristic $^{14-15}$. However, a research ${ }^{16}$ reported that the highest concentration of cases in women can be derived from the higher use of health services by this group when compared with men, resulting in possible notification obliquity.

In the present research, the age group that obtained the highest number of confirmed cases of dengue was between 15 and 49 years old, with 10,252 cases, when compared with the 6,210 cases in the other combined age groups. A similarity was observed with studies ${ }^{6,17}$ performed in the municipalities of São Luis (MA) and Belém do Pará (PA), whereas a study performed in Manaus identified a higher occurrence of dengue in 15-year-old minors.

In conclusion, it was verified that there was a significant increase in the proportion of dengue cases in 2008, in the City of Aracaju (SE). However, a fast decline was noticed in the other years, possibly because of the intensification of preventive actions to combat the mosquito that transmits the dengue virus. Therefore, the public politics of health should adopt and maintain preventive actions through health education, basic sanitation, good residence conditions, as well as motivating control actions and participation in the community, with an awareness of the factors that facilitate vector procreation.

\section{ACKNOWLEDGMENTS}

We thank the Epidemiological Vigilance Coordination of the Municipal Office of Health of Aracaju for providing the necessary data for the conduct of this study.

\section{CONFLICT OF INTEREST}

The authors declare that there is no conflict of interest.

\section{REFERENCES}

1. Maciel IJ, Siqueira-Júnior JB, Martelli CMT. Epidemiologia e desafios no controle do Dengue. Rev Pat Trop 2008; 37:111-130.

2. Braga IA, Valle D. Aedes aegypti: histórico do controle no Brasil. Epidemiol Serv Saude 2007; 16:113-118. 
3. Organização Mundial de Saúde. Dengue hemorrágica: diagnóstico, tratamento, prevenção e controle. São Paulo: Editora Santos; 2001.

4. Rocha LA, Tauil PL. Dengue em criança: aspectos clínicos e epidemiológicos, Manaus, Estado do Amazonas, no período de 2006 e 2007. Rev Soc Bras Med Trop 2009; 42:18-22.

5. Keating J. An investigation into the cyclical incidence of dengue fever. Soc Sci Med 2001; 53:1587-1597.

6. Gonçalves Neto VS, Rebêlo JMM. Aspectos epidemiológicos do dengue no município de São Luis, Maranhão, Brasil, 1997-2002. Cad Saude Publica 2004; 20:1424-1431.

7. Melo MSS, Barreto FR, Costa MCN, Morato VC, Teixeira MG. Progressão da circulação do vírus do dengue no Estado da Bahia, 1994-2000. Rev Soc Bras Med Trop 2010; 43:139-144.

8. Nogueira RMR, Schatzmayr HG, Filippis AM, Santos FB, Cunha RV, Coelho JO, et al. Dengue Virus type3, Brazil, 2002. Emerg Infect Dis 2005; 11:1376-1381.

9. Barreto ML, Teixeira MG. Dengue no Brasil: situação epidemiológica e contribuições para uma agenda de pesquisa. Rev Estudos Avançados $2008 ; 22: 53-72$

10. Câmara FP, Santos GT. É possível controlar a dengue? Rev Soc Bras Med Trop 2010; 43: 754-755

11. Câmara FP, Theophilo RLG, Santos GT, Pereira SRFG, Câmara DCP, Matos RRC. Estudo retrospectivo (histórico) da dengue no Brasil: características regionais e dinâmicas. Rev Soc Bras Med Trop 2007; 40:192-196.

12. Consoli RAGB, Oliveira RL. Principais Mosquitos de Importância Sanitária no Brasil Rio de Janeiro, Rio de Janeiro: Editora da Fundação Oswaldo Cruz; 1994

13. Teixeira MG, Barreto ML, Costa MCN, Ferreira LDA, Vasconcelos PFC, Cairncross S. Dynamics of dengue vírus circulation: a silent epidemic in a complex urban área. Trop Med Int Health 2002; 7:757-762.

14. Oliveira RM, Valla VV. As condições e as experiências de vida de grupos populares no Rio de Janeiro: repensando a mobilização popular no controle do dengue. Cad Saude Publica 2001; 17:77-88.

15. Vasconcelos PFC, Travassos da Rosa ES, Travassos da Rosa JFS, Freitas RB, Degallier N, Rodrigues SG, et al. Epidemia de febre clássica de dengue causada pelo tipo 2 em Araguaína, Tocantins, Brasil. Rev Inst Med Trop São Paulo $1993 ; 35: 141-144$

16. Flauzino RF, Santos RS, Barcellos C, Gracie R, Magalhães MAFM, Oliveira RM Heterogeneidade espacial da dengue em estudos locais, Niterói, RJ. Rev Saude Publica 2009; 43:1035-1043.

17. Nascimento DMB, Coelho RN, Rodrigues SG. Diagnóstico laboratorial da dengue no município de Belém - Pará: a atuação do Laboratório Central do Estado do Pará. Rev Soc Bras Med Trop 2003; 36:484-485. 